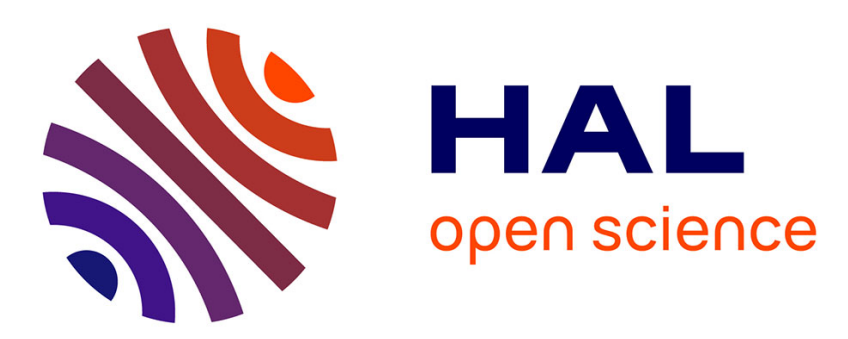

\title{
The Double Necessity of Criticism and Self-Effacement: Paulhan and Fénéon
}

\author{
Brigitte Ouvry-Vial
}

\section{To cite this version:}

Brigitte Ouvry-Vial. The Double Necessity of Criticism and Self-Effacement: Paulhan and Fénéon. Yale French Studies, 2004, The Power of Rhetoric, the Rhetoric of Power: Jean Paulhan's Fiction, Criticism, and Editorial Activity, 106, p. 26-36. 10.2307/3655212 . hal-02117279

\section{HAL Id: hal-02117279 https://hal.science/hal-02117279}

Submitted on 2 May 2019

HAL is a multi-disciplinary open access archive for the deposit and dissemination of scientific research documents, whether they are published or not. The documents may come from teaching and research institutions in France or abroad, or from public or private research centers.
L'archive ouverte pluridisciplinaire HAL, est destinée au dépôt et à la diffusion de documents scientifiques de niveau recherche, publiés ou non, émanant des établissements d'enseignement et de recherche français ou étrangers, des laboratoires publics ou privés. 


\section{Yale UNIVERSITY PRESS}

The Double Necessity of Criticism and Self-Effacement: Paulhan and Fénéon Author(s): Brigitte Ouvry-Vial, Michael Syrotinski and Martyn Cornick

Source: Yale French Studies, No. 106, The Power of Rhetoric, the Rhetoric of Power: Jean

Paulhan's Fiction, Criticism, and Editorial Activity (2004), pp. 26-36

Published by: Yale University Press

Stable URL: https://www.jstor.org/stable/3655212

Accessed: 02-05-2019 08:35 UTC

JSTOR is a not-for-profit service that helps scholars, researchers, and students discover, use, and build upon a wide range of content in a trusted digital archive. We use information technology and tools to increase productivity and facilitate new forms of scholarship. For more information about JSTOR, please contact support@jstor.org.

Your use of the JSTOR archive indicates your acceptance of the Terms \& Conditions of Use, available at https://about.jstor.org/terms

Yale University Press is collaborating with JSTOR to digitize, preserve and extend access to Yale French Studies 


\section{The Double Necessity of Criticism and Self-Effacement: Paulhan and Fénéon}

When Jean Paulhan first published F[élix] F[énéon] ou le critique [Félix Fénéon or The Critic] in 1943, the work attracted much comment in review articles and private correspondence, drawing attention, more or less explicitly, to the apparent relationship between the author and Fénéon, the subject of his study. ${ }^{1}$ Marcel Arland spoke of "identification and mythification," André Billy wrote that Paulhan's personal preference for Fénéon could be explained by the fact that "his own role in literature was the same as that of Fénéon in painting," and Raymond Guérin noticed in both Paulhan the man and in his work "his close affinity with Fénéon, so much so that everything said about Fénéon could be said about Paulhan." Guérin turns to Paulhan the writer in order to find the effects and the application of the critical principles and approaches he highlights in his book on Fénéon. The same is true of André Wurmser, who considers that the definition of the ideal critic - that is, someone who, having understood that the true nature of the critic is to remain invisible, deliberately remains silent-is yet further "disappointing" (décevante) proof of Paulhan's predilection for mischief and paradox. ${ }^{2}$

Alexandre Astruc was the first to shift the focus away from Paulhan's critical essays and his contribution as a writer to concentrate on the part he played in the literary life of his time; he considered $F F$ ou le

1. First published in Confluences 26 (1943). Recent re-edition FF [Félix Fénéon] ou le critique (Bassac: Éditions Claire Paulhan, 1998), which gathers together in a very useful appendix ("dossier critique") the review essays to which I will be referring. Subsequent references to $F F$ ou le critique, abbreviated as $F F$, will appear in parentheses in the text, directly following the quotation.

2. The articles by Billy, Guérin, and Wurmser are reprinted in FF ou le critique, ed. cit., 136, 146, and 165 .

YFS 106, The Power of Rhetoric, the Rhetoric of Power, ed. Michael Syrotinski, (C) 2004 by Yale University. 
critique to be the very moment when Jean Paulhan, "having completed the portrait of his model, at last reveals something of himself" and abandons his legendary "discretion." André Berne-Jouffroy, and even more so Maurice Blanchot in his "Mystère de la critique," while they do not establish a clear parallel between the author and his model critic, underline the central point of Paulhan's argument, an argument championed as much by Paulhan as by Fénéon: the idea that the self-effacement of the individual ensures the triumph of the individual; that the defense of literature and the refusal to follow the taste of one's time is best achieved through silence. For his part, Maurice Nadeau adds that this silence goes hand in hand with an "intellectual attitude" that, as a mixture of contradictory features, is "hard to imitate": "denials and acceptances, self-confidence and humility, enthusiasm and critical distance, carelessness and wisdom, judicious appreciation of literature and an even more definite refusal of illusion." In other words, a composite portrait of an editor, or rather of Jean Paulhan as editor. In the same article, Nadeau notes that if Paulhan, under Fénéon's influence, advocates critical silence, and promotes the ideal of a criticism that does not engage in criticism, this is not in order to undermine criticism, but to suggest that Fénéon's approach is an example of a kind of supreme loyalty toward art, just as Paulhan's is toward literature. ${ }^{3}$ For Paulhan the naturalist, Fénéon represents a specimen well adapted to his favored approach, which consists in observing closely, dissecting, and describing "with devilish patience" $(F F, 56)$.

It is not my intention here to examine the similarities between Paulhan's and Fénéon's respective methods and approaches to criticism, similarities that are explained partly by a didactic imitation of the latter by the former. I would like instead to turn my attention to another more subtle but meaningful similarity, namely the "disappointment" that Paulhan identifies in Fénéon-"a disappointment that is so consistent and, I might add, legitimate, that one can easily imagine it takes us right to the heart of Fénéon" (FF, 71). This disappointment, in other words, hints at hidden meanings that are so insightful and startling that Paulhan's reader also repeatedly experiences them. At the beginning of his essays, for example in Petite préface à toute critique (Short Preface to All Criticism) in talking about the notion of judgment, or in Essai d'introduction au projet d'une métrique universelle (Attempt at an Introduction to the Project of a Universal

3. Quotes from Astruc, Blanchot, and Nadeau in ibid., 124, 119, and 158. 
Metrics) when he discusses the observation of thought, Paulhan the naturalist often relies on a systematic description of his objects in order to provide a first approach or definition. He singles out the object of his study as if this were a unique case, defines it in an a priori manner and then enumerates its components and main features. His purpose is to give a broad yet synthetic overview of a complex reality before questioning this reality and trying to solve its apparent or inherent contradictions. While Paulhan's aim in Essai d'introduction au projet d'une métrique universelle is seemingly to reveal the writer's secret or to find "an acid that would expose the thought process," onomy is complete, he remains trapped by the system he has established, and by the complexity he has described. Language, he argues, is self-referential, and the images we have of our thoughts are merely the projections of our efforts to observe our thoughts. Language itself is the very projection that we are able freely to observe, whence the inextricable connection between word, idea, and thing.

The disappointment is perhaps felt as much by Paulhan himself as by his reader, eager to make his own discovery, but it comes out of Paulhan's choice of a kind of critical realism, in contrast to the "boldness" (hardiesse) he posits in A demain la poésie (Tomorrow's Poetry), ${ }^{5}$ or to the direct apprehension of thought suggested by Henri Michaux (especially in narratives relating his experiments with drugs), as letters between Paulhan and Michaux attest. Whereas Paulhan dreams about an acid that would reveal thought processes and allow them to be observed, Michaux, with the same aim in mind, carries out actual experiments with this acid.

This disappointment at work in Paulhan's essays elsewhere takes the form of a detailed description of an object, presented as a preliminary and necessary step prior to the analysis and explanation of the mystery studied, which is then rarely followed by the expected explanation; at most we get an approach to, or nuanced approximation of, this mystery, and its indirect effects. Time and time again, a definition is followed by a counter-proposition, or a retraction that cancels it out: "I think that here we'd have to say the opposite" (FF, 28). Whether it is a question of the direct apprehension of thought, the attempt to penetrate the secret of poetry, or determining the nature of illusions or even of commonplace expressions (which are for Paulhan the sign of failure,

4. Essai d'introduction au projet d'une métrique universelle (Paris: Le nouveau commerce, 1984), 9.

5. A demain la poésie (Paris: Le nouveau commerce, 1983). 
of a breakdown in communication and disappointment for the reader, but for Michaux the sign of success, and the proof that the shortest route has been found), we are concerned less with what is at stake here, theoretically speaking, than with the motivating force behind what appears to be an organized and deliberate disappointment. Indeed, how can we explain this collapse of the demonstration, this failure to account for the complexity of the mystery envisioned and described? Why is it that Paulhan would rather restrict himself to an undeveloped critical method than attempt to discover the secrets of language through the intimate experience of personal writing? Is it because he doubts his abilities and talents as a writer? Or is it because he hopesand hope, says Paulhan, is an essential element in criticism-that this critical self-discipline, which aims neither to control nor to predetermine anything, will lead to a revelation, the surprising discovery of a kind of beauty within mystery?

This tactic of remaining discreet, while hoping and waiting for a major work of literature to come along, is not something we associate with a critic, but rather an editor or publisher. George Perros emphasizes this trait of Paulhan when he says: "In order to understand better the other person, he disappears, becomes an empty vessel, allows himself to be carried along as on the breeze." He adds, pointing out how Paulhan preferred to remain in the background: "If anything marks him out, it is his passion for going incognito, for remaining clandestine. This is a demanding passion because it requires complete withdrawal from oneself, leaving only the slightest trace in the sand. ${ }^{\prime 6}$ For Paulhan, it is the editor's duty or imperative, while exercising his critical faculties, to maintain a freshness of perspective, one that is stripped of literary expertise, and that represents the viewpoint of the average reader, or the "man-in-the-street," le premier venu to whom Paulhan frequently makes reference. For him, the editor's or publisher's role is to anticipate, on the basis of her own understanding and reading of a text, what the reaction of her reader will be. Since the average, or potential reader is not bothered about critical or scholarly considerations, the publisher makes the decision whether or not to publish a text on the basis of both her anticipation of this reader's reactions, and her own impressions, which she wants to keep as open and direct as possible. So this "disappointment" contributes to the endlessly surprising nature of Paulhan's writing and, as he himself suggests in talking about Fénéon, it takes us

6. Georges Perros, Papiers collés III (Paris: Gallimard, 1978), 164. 
"right to the heart" of Jean Paulhan $(F F, 71)$, unless we entertain the possibility that Paulhan's contemporaries were victims of a giant hoax, as are we, and that Paulhan was merely a lucid but frustrated writer who became an editor and publisher out of a personal inability to write, or because he feared he would not meet his own high critical standards.

Obviously, this explanation lacks credibility. Paulhan became an editor willingly and must have known what this involved. He suggests as much in FF ou le critique in the chapter entitled "Colonel Cody or the Choice of a Profession" (FF, 77). Paulhan was appointed as Jacques Rivière's secretary at the Nouvelle revue française after Rivière indicated that he wished to concentrate on his own literary writing. He respectfully submitted to Gide's tutelage in order to distance himself all the more from Gide's critical practice. Although Paulhan was convinced that the major literary works of his time (those of Valéry, Proust, Gide, Joyce, Claudel) were born out of a systematic critical approach to literature, he was also aware of the limits of this approach for the author's own work: "A good half of their œuvre," he says, "is spent proving that they were right to write the other half." ${ }^{17}$ As far as Paulhan is concerned, the criticism written by these authors has no relevance outside their own work, and moreover it serves no other purpose than to explain itself. Indeed, the author who first introduced him into the Nrf, André Gide, must have provided for Paulhan a clear example of the critical strategy of a writer who, under the guise of impartiality, limited his criticism to "authors distant from himself," and "refused to quote his friends, " but whose aim was above all to "affirm his own uniqueness." 8 W. Somerset Maugham, in the foreword to Of Human Bondage, and in the context of this period in French literature, reaches a similar conclusion:

An author is probably the last person who can write fitly about his own work. In connection with this an intuitive story is told by Roger Martin du Gard, a distinguished French novelist, about Marcel Proust. Marcel Proust wanted a certain French periodical to publish an important article on his great novel and thinking that no one could write it better than he, sat down and wrote it himself. Then he asked a young friend of his, a man of letters, to put his name to it and take it to the editor. This the young man did, but after a few days the editor sent for him. "I must refuse your article," he told him, "Marcel Proust would never forgive

7. Petite préface à toute critique (Paris: Éditions le temps qu'il fait, 1988), 13.

8. Frédéric Martel on André Gide, Essais critiques (La Pléiade, Gallimard), in La nouvelle revue française 550 (June 1999): 332. 
me if I printed a criticism of his work that was so perfunctory and so unsympathetic." Though authors are touchy about their productions and inclined to resent unfavourable criticism, they are seldom self-satisfied. They are conscious how far the work on which they have spent much time and trouble comes short of their conception, and when they consider it are much more vexed with their failure to express this in its completeness than pleased with the passages here and there that they can regard with complacency. Their aim is perfection and they are wretchedly aware that they have not attained it. ${ }^{9}$

Paulhan's willing and conscious decision to take up the reins of the review, along with his insightful understanding of the editor's versus the author's relative advantages as a critic, go some way toward explaining his strategy of disappointment. Paulhan seems to use disappointment as a way of resisting the self-disappointment that would result from restricting himself to one mode of writing or a single critical system, rather than experiencing all possible forms.

In FF ou le critique, Paulhan clearly emphasizes the artist's role as creator of his own world, or of a language in which he is able to present and affirm himself, but within which he can also languish, and become trapped and repetitive. This deliberate disappointment is thus a sign of life and of freedom of action, or of loyalty to literature, with all the hopes and expectations that are invested in it. It is a calculated disappointment that guides the famed evasiveness [pratique de l'esquive] that Paulhan's contemporaries so often referred to in talking of him. Maurice Nadeau described it as a system of opposites: negation/acceptance, self-affirmation/self-effacement, foolhardiness/wisdom, and so on. This evasiveness is apparent in the way in which, in his correspondence, he praises while criticizing, encourages authors while refusing their work, and in his use of understatement and asides. Françoise Simonet-Tenant, in her edition of the correspondence between Paulhan and Catherine Pozzi, draws attention to the importance of his parenthetical remarks and comments in the margins: "It is there," she says, "that one finds the nucleus of the letter, for in order to be understood, it must have the appearance of a marginal and secondary argument." ${ }^{10}$ We can also see this in the various depictions of Paulhan as a kind of acrobat, or in the famous sequence of terms used by Geroge Per-

9. W. Somerset Maugham, Of Human Bondage (London: Heinemann, 1915, 1973 reprint), v-viii.

10. Correspondance Catherine Pozzi-Jean Paulhan, edition annotated and introduced by Françoise Simonet-Tenant (Bassac: Éditions Claire Paulhan, 1999), 84. 
ros to describe him: "Paulhan the gold prospector, Paulhan the subversive, Paulhan the intellectual dancer." ${ }^{11}$ This evasiveness is a tried and tested professional skill that is exploited to the full in his editorial activity.

Its significance and purpose is suggested to us in the portrait of Félix Fénéon that Paulhan gives us. This portrait-which is, as Marcel Arland pointed out, intriguingly "partial"12 -is as close as one gets to self-praise in Paulhan. The goal toward which he is striving-which Félix Fénéon inspires in him, but which no doubt he alone is able to conceive of and reach-is the revelation of a previously unknown and unidentified category of thought and means of creation that would give meaning and nobility to the editorial act, and would take the form, as Paulhan puts its, "of writing without leaving behind a trace" (FF, 80). There is no criticism without a trace, a critic who does not write is not a critic. The trace is the very object of criticism. The editor or publisher is the only one able to take up this challenge, since she could be seen as an inventor who does not just casually admire-admiration being fragile and ephemeral-but who also acts, who leaves behind a trace of her judgment when she follows through with it in her decision to publish, and who thus demonstrates the very "firmhandedness" [poigne] that Paulhan says is singularly lacking in critics (FF, 33). There is, of course, also the more obvious role an editor plays in producing a book while her name does not appear on the cover, or in helping to write a text that she will not sign, and which thus retains no explicit trace of her name, or her work as a critic and writer. The work of an editor is thus the place where we see true literary criticism at work, if we measure it according to Paulhan's simple but extraordinary definition, that is, a "critical reflection that determines whether a work of literature deserves to be considered or not, whether it exists or not, whether it is, in short, good or bad. It is at the point where two forms of criticism meet; one precise but too specialized, the other more expansive but too vague." It is, as he says a little later on, "another name for attention."13

While his texts ostensibly are simple reflections on criticism and the mystery of literature, Paulhan is in fact engaged in an attempt to capture this mystery, and to define an art and an artfulness that are first and foremost his own. Criticism is central to the whole range of Paul-

11. Perros, op. cit, 158.

12. FF ou le critique, quoted by Claire Paulhan in her introduction, 16.

13. Petite préface à toute critique, op. cit., 14. 
han's literary activities, whether it is directing a review, giving editorial advice, corresponding with the authors, or within his own writing, in which the critique of criticism, as we know, occupies a privileged place. What all of these activities share is the search/endlessly renewed and yet apparently interminable) for the essence of literature. He is not interested in being the "hard-working slave" of poets and novelists, nor of falling into the common trap of excessive piety, and neither does he wish to impose his own standards and ideological perspective. The absolute attention Paulhan would like to give to literature is indicative of a desire, the fulfillment of which absorbs him completely, to be able to identify the "end point" [point d'accomplissement] of a work, which alone determines its beauty. This "end point" is a geometrical term, and it reveals Paulhan's practical approach to writing and reading literature, since he feels able to measure success or completion in a work of art, as well as its capacity to touch the reader, and the effects it is likely to have. Determining the end point of a work presupposes that one has the tools to measure it /these being an understanding of how language works, and of its rules) and also a particular sensitivity to the operations of illusion and representation. This implies the ability to see things both from the perspective of the author, in order to understand what he or she is trying to do, and to measure whether he or she has succeeded, and from the reader's point of view, to test how effective the author's intentions in fact are. Indeed, one could even say that Paulhan's reflections on these questions in his critical essays, along with his editorial practice, make him an early precursor of reception theory.

He goes further, though, and here again his observations on the pitfalls and errors of criticism inform his understanding of the editorial act. In order to determine this end point, one has to have the appropriate critical tools and faculties at one's disposal, but more importantly one has to have assimilated them, and be able to use them lightly, discreetly, almost instinctively, rather than wheeling out the heavy artillery of theory. This implies, as Paulhan says in Petite préface à toute critique, "a more or less complete reduction of the errors or illusions"14 that one can find in rhetorical operations and linguistic rules, or in the works of writers-artists and critics alike-who fail to meet the criteria of the truth about language that this reduction establishes. When Paulhan talks of a "more or less complete reduction," this should be understood not in the sense of "eradication," but as an algebraic oper-

14. Ibid., 37. 
ation performed on fractions reduced to a common denominator. This reduction is Paulhan's central objective, and is one that explains and justifies the disappointment experienced. It matters little whether the demonstrations in his essays are a success from a scientific point of view, since Paulhan is not trying to convince us, or to settle an argument one way or another. What he is attempting to do, by means of a logical analysis of how criticism functions, is to achieve the reduction of errors and illusions that is a necessary prelude to being able to give texts the attention they deserve in an editorial situation. One could say that Paulhan's critical writings were all in a sense early drafts, or a kind of workshop or preparatory training, for the major work in progress of his life, that is his activity as an editor.

The notion of an "end point of a work" that alone makes it possible to speak of its beauty, is symptomatic of a romantic or properly mystical approach to reading literature, even though Paulhan in a sense wanted to make it a kind of science. If the theory of this science is developed throughout his essays, it is in his editorial practice that he puts it into action. His essays thus have a dual purpose. First of all they serve every so often to sharpen the critical tools that have lost their edge in the fragmented, scattered activity of editing manuscripts and of managing a literary review (and this dispersion, or the risk of dispersion, is more likely to be true of the work of an editor of a review than of a publisher, or an editor of a collection). One has only to look at the history of the Nrf to get an idea of the many different tasks Paulhan was required to perform, and the situations in which his judgment was called upon: reading and editing manuscripts, proofreading texts and reviews, sending out the proofs, reviewing published texts, answering letters, receiving authors, advising and nurturing them, coming up with ideas for issues and deciding what to include in them, dealing with practical considerations such as page length or delays in submission, and the myriad other details in which he was in danger of losing sight both of the overall coherence of the review and of its guiding principles. From this perspective, his critical essays provide a space in which he is able to gather his thoughts together again. Secondly, and as a consequence of the first, they allow him to return to his own personal, intimate ideas about literature that were perhaps lost after so much time spent working on other writers' texts. This is what Paulhan suggests in FF ou le critique when he talks of the "new and more efficient language" (langue neuve et efficace) that critics must forge for themselves, but that at the same time they must resist using in their own work (FF, 72). 
This aim, which is apparent in his activities as the editor of a review (at least in the accounts and testimonies we have, and in his correspondence with other writers), could explain why Paulhan would often change the way he wrote depending on the person to whom he was writing, and would thereby connect with the other person while remaining himself. One might advance the hypothesis that this aim ensured a certain continuity between his work as an editor and his work as a writer, allowed him to organize his working day, and to remain committed to his single vision of literature as a search for what is instantaneous, or elementary. He suggests as much in a note on the correspondence of Jules Renard: "Jules Renard is one of three writers in the nineteenth century, the other two being Rimbaud and Mallarmé, who see literature as a sacred event. They see it precisely in that instantaneous quality [dans l'instantané] of literature, which can only be perceived in a sudden burst, and be contained within one sentence. When I say a sentence, I mean a single main clause without any subordinate clause. Jules Renard or the art of the elementary." ${ }^{15}$ FF ou le critique is exemplary in this regard, insofar as Paulhan's analysis is drawn to Fénéon's short propositions, his incisive sentences, his three-line short stories, and so on. This continuity between his two activities also, paradoxically, links the essential noncontinuity that characterizes both his profession as an editor and his written oeuvre itself, which André Dhôtel described as "literature traversing both of them, erupting suddenly and illuminating them briefly in the apparent dispersion and the uncertain convergence of his essays." 16 On the one hand we have an oeuvre that eludes and disappoints us at its very moment of conclusion, and on the other we have an oeuvre that does not identify itself as such, and that only leaves indirect traces (albeit an enduring impression on our memory): the published works of many of the finest writers in France, the reputation of the Nouvelle revue française, and the indisputable and proven influence of a man of letters over a whole generation of his contemporaries.

In this sense one could say that Jean Paulhan-for whom the word "writer" applied equally, but in distinctively different ways, to both the author of a work and the critic who talked about it-saw his editorial activity as a means of "writing without leaving behind a trace," and of

15. Quoted by Jean-Yves Tadié in Le récit poétique (Paris: Gallimard, 1994), 102.

16. André Dhôtel, "Jean Paulhan et le mystère," in La nouvelle revue française 197, (May 1969): 669. 
attaining the "mysterious glory" $(F F, 35)$ he sought. The fewer traces and signs the editor leaves behind of his intervention, the more this "nothing" toward which he strives in order to ensure the greatest possible transparency of the work becomes something remarkable, something that is a true mark of distinction. Only an editor is capable of performing this extraordinary feat, of accomplishing this paradoxical task, just as he is also the only one to know how he managed to do it. This is amply demonstrated if we consider the list of qualities he attributes to Félix Fénéon, which he sees almost as the ethical imperatives of criticism, and if we then apply them to the role of the editor, not only the editor that Jean Paulhan was, but the function of an editor in general. An editor is indeed someone whose role is:

- to react to a work of literature and sometimes to keep quiet about it, or at most to blush $(F F, 57)$;

- to know and master each and every theory about literature, but not to favor any one in particular, since it is a matter not of persuading anyone, but of communicating properly $(F F, 90)$;

- to "be able to appreciate the literary creations of living authors," and to be "a critic of the present day and age" (FF, 32);

-to "make the world created by writers accessible to us" (FF, 27), to be a kind of messenger, but also an inventor;

-to hide behind his invention, which at times means having others sign what he has written himself.

For Paulhan an editor was a shadowy figure, someone who invents his authors, who is a polyglot and a polygraph conversant with each and every one of their languages, and who, like Félix Fénéon before him, should be able to enrich and inspire us. Now that this figure of the author who is also an editor or publisher seems to be a dying breed, and we seem to be entering a radically new age of "publishing without publishers, ${ }^{\prime 17}$ it is all the more vital nowadays that editors and publishers articulate with rigor their particular critical commitments, and the ins and outs of their professional activities. In this respect, as in many others, Jean Paulhan's contribution was exemplary.

- Translated by Michael Syrotinski, with Martyn Cornick and the author.

17. Since I, too, am an editor, my thoughts on this particular dimension of Jean Paulhan's editorial practice constitute at the same time a reflection on my own practice. 